\section{ONOMAREDIN}

Revista semestral de lingüística, filología y traducción
PONTIFICIA UNIVERSIDAD

\title{
Register of the Translated Vocative Sentences in Qur anic Texts into English
}

\author{
Nida S. Omar \\ University of Malaya \\ Malaysia
}

\section{Salahuddin Bin Mohd}

University of Malaya

Malaysia

\author{
Kais A. Kadhim \\ University of Malaya \\ Malaysia
}

ONOMÁZEIN 29 (junio de 2014): 152-163

DOI: 10.7764/onomazein.29.8

(c) $(i)$

Nida S. Omar: English Department, University of Malaya. Malaysia. Correo electrónico: nidaa.omar@gmail.com

Salahuddin Bin Mohd: Arabic Department, University of Malaya. Malaysia.

Correo electrónico:Xtre_zar@yahoo.com

Kais A. Kadhim: English Department, University of Malaya. Malaysia.

Correo electrónico: Kaisamir2002@yahoo.com 


\section{Abstract}

In general, a vocative sentence is used to attract the attention of the addressee. Occasionally, a new meaning is determined by the context when the vocative sentence veers away from its original meaning to produce different purposes, such as reprimand, exclamation, allurement, recollection, call for help, particularization, and grief. We investigated the rhetorical message of English Qur'anic vocative sentences rendered in terms of language variables in a context of situation. We aim to obtain an adequate answer to the question "What is the extent of the sus- tenance of the rhetorical message in English translation in terms of (field, tenor, and mode) functions compared with the same terms in the original message?" The data were collected from various chapters of the Qur'an. The rendered data were analysed according to the register's theory of Halliday and Hassan (1985) to track the differences in the rhetorical message of Arabic and English. The rhetorical message was not preserved entirely, only occasionally. We present a practical study for new translators who are interested in religious translation.

Keywords: vocatives; translation; register; Qur `an. 


\section{Introduction}

The context of situation comprises a range of meanings that function under specific conditions by using words and structures to produce meanings (Halliday, 1978: 23). Morley (1985) points out that the context of situation is a setting that involves linguistic acts occurring in its orbit. Register analysis allows the discovery of how language is manoeuvred to produce meaning. The process of translation affects the Qur'anic vocative sentences when converted into English. Translation occasionally offers another meaning of the original message and consequently affects the rhetorical meaning of the vocative sentences. Therefore, this study attempts to determine how the rhetorical message is retained in the English translation in terms of field, tenor, and mode compared with the original texts. We present a guide for translators who are interested in religious translation and in comparative studies.

\section{Vocative in Arabic language}

Vocative is a direct speech that is used to catch the attention of the addressee by using particles such as hamza, yā, ay, aya, haya, $\bar{a}$, and wà (calawī, 1982; Qazwinī, 1983). In general, Arab rhetoricians have classified vocative speech into two types, namely, constative (al-habar) and performative (al-ainsh $\left.\bar{a}^{0}\right)$. Vocative is a branch of the performative (alinshã). Various kinds of vocative sentences in the glorious Qur'an have been differentiated by Arab rhetoricians. Some of these sentences show rhetorical purposes, but some do not. Our study concentrates on one rhetorical purpose used in the glorious Qur'an, and such purpose has no specific structure. However, its meaning is inferred from the context of grief (al-tahasur) (Abu Musa, 1987; Zawbacī, 1997; Fūd, 1998)

\section{Methodology}

Vocative sentences with four rhetorical purposes are collected from the entire Qur'an. These data have been provided with their En- glish translation by Yusuf Ali (2006) and were analysed in terms of register's theory (context of situation) and according to Halliday and Hassan (1985), which is summarized below.

\subsection{Context of situation}

According to Halliday and Hassan (1985), the context of situation (register) is argued in terms of three variables, namely, field, tenor, and mode. Field indicates "the subject matter," which is the social action involved in the situation, and the role of the language in that specific situation. Tenor indicates the participants in the situation and the roles, nature, and the status of the participants. Tenor also refers to the relationship and the kind of relationship among the participants. Mode indicates the function of the language in the situation. What do participants expect the language to do for them in a given situation? How will the organization and structure of the text help participants obtain their objective? (1985: 12). The meaning of the text is realized by three fundamental functions of the context of situation. These functions are represented by ideational, interpersonal, and textual meanings. Such functions and variables of register (field, tenor, and mode) are interrelated. Field, tenor, and mode are connected with ideational, interpersonal, and textual meanings, respectively (Halliday, 1978: 143). From a translational viewpoint, these variables and functions must be considered in the process of translation to highlight the differences in the context of situation in terms of field, tenor, and mode between any two languages. The context of situation in the vocative sentences might charge overt and covert meanings in the process of translating such sentences into English because our study is Qur 'anic data. Therefore, we chose this theory in this study.

\section{Data Analysis}

The data of this study comprise six vocative sentences collected from the Qur 'an, and translated into English by Yusuf Ali (2006). These data 
were analysed in terms of field, tenor, and mode to determine the extent of the retention of the rhetorical message in both Arabic and English.

\subsection{Grief Rhetorical Purpose}

$\operatorname{Data}(1)$

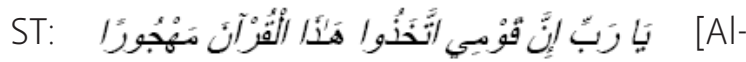 Furqan, verse 30] \\ Trs: Yā rabbī inna qawmī ittahadūù had̄ā al- qurān mahjūran}

TT: O my Lord! Truly my people took this Qur `an for just foolish nonsense (Ali, 2006: 896)

a) Field

This Qur'anic vocative sentence expresses the sadness of the prophet Muhammad (PUH) because his people refuse to listen and believe in the Qur 'an. This feeling of sadness is established with the use of the vocative particle '

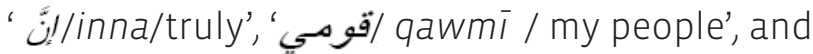
'مهجور/ mahjūran / for just foolish nonsense'. The feeling of sadness is expressed in the vocative sentence, including the declarative sentence. Explicitly, the same event that occurs in the ST has been slightly altered. The translator expresses the ST ' معجور/ mahjūran / for just foolish nonsense' as foolish and nonsense. Therefore, the field of the English translation slightly diverges from its original meaning of "abandoned" to "foolish and silly thing". Consequently, the rhetorical meaning of the ST becomes slightly different. The field in the original has been disrupted because of the meaning of "foolish and silly." Thus, the translation is faulty.

\section{b) Tenor}

The prophet Muhammad (PUH) calls the Almighty and expresses extreme grief because of the actions of his people. The people continue to refuse to listen to the Qur 'an. Subsequently, the prophet conveys this feeling by using the vocative. In addition, the Qur 'anic vocative sentence indirectly alerts and warns the people because the prophet has forwarded his grief, and requested for help from the Almighty. The trans- lator has retained the role of all the participants with a slight difference. The translator's idea of the meaning of 'مهجور / mahjūran / for just fool-

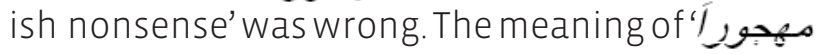
I mahjüran / for just foolish nonsense' was disrupted and was presented as foolish. Thus, the tenor of the TT is somewhat distorted, and the translated outcome of the rhetorical meaning is semi-accurate.

c) Mode

The prophet conveys his grief by using a vocative sentence, which implies the use of a declarative sentence. Numerous lexical items have been used as implements to convey grief. The vocative particle ' who is near or far from the speaker. In this case, the prophet Muhammad calls Allah by means of the vocative particle ' tent of his sadness and the direness of his situation. The prophet uses this statement because he knows that Allah is near him. The translator has retained this significance in his translation by converting the vocative particle ' "O." The translator has kept the noun phrase (NP) ' “بَّ / yā rabbi / O, my Lord!' in the TT followed by a comma to retain the meaning of the ST NP

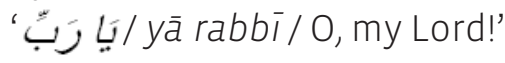

In addition, the determiner (D) 'إنَّ/inna/truly,' as mentioned in the previous example, is a particle that functions as a quasi-verb, which is used to emphasize the subsequent action or statement. In this case, the (D) 'إنّإن/inna/truly' is used to assert a particular issue, such as the grief of the prophet Muhammad (PUH) and the situation where his people (not other people) refuse to listen to the Qur' an. The translator has preserved the metafunction of the D 'إنّ/inna/truly' in the TT and translated such metafunction into an accurate equivalent (i.e., 'truly').

The lexical item 'قومسي / qawmi / my people' is used to confirm the degree of his grief caused by the behaviour of his people because they are supposed to agree with him and accept his mis- 
sion as a messenger of Allah. In addition, the de-

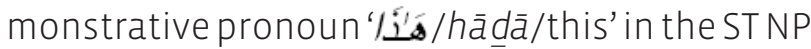

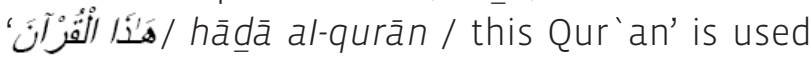
to refer to a thing. In this context, the pronoun is used as an anaphoric reference to the Qur 'an, and also has other thematic foci. The pronoun is used to glorify the glorious Qur' an, and that such a book should not be abandoned. The TT has retained the same structure of the ST

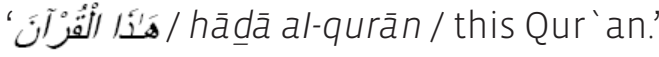

Finally, the lexical item ' مهجور/ mahjūran / for just foolish nonsense' has a thematic focus in this vocative sentence, and means vacant. The people of prophet Muhammad (PUH) failed to pay attention to the reading of the Qur 'an, and failed to realize what it contains. This thematic meaning is missing in the translation. The translator has failed to retain the core of the ST, namely, 'مهجور/ mahjūran / for just foolish nonsense.' Grammatical and semantic changes were made. The translator changed the N 'مهجور/mahjūran' to the prepositional phrase (PP) 'for just foolish nonsense.' Hence, the translator missed the real meaning of the ST 'مهجور /mahjūran.' The translated version means "for just funny" or "silly

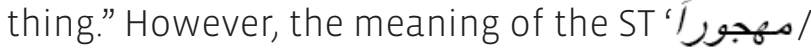
mahjüran' is "abandoned." This shift in focus slightly distorts the rhetorical meaning of the ST. Consequently, the translation has partially affected the context of the abovementioned vocative sentence.

\subsection{Lamentation Rhetorical Purpose} $\operatorname{Data}(2)$

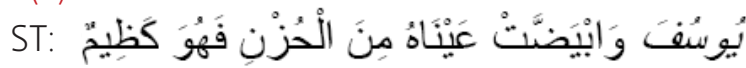
[Yūsūf, verse 84]

Trs: Yãa oasāfā calā Yūsūfa

TT: How great is my grief for Joseph! (Ali, 2006: 574)

a) Field

The verse expresses the lamentation of the prophet Jacob over the loss of his dearest son Yūsūf. Such lamentation is signified by the

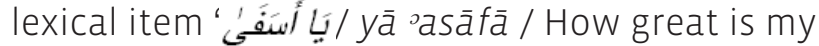
grief,' which conveys sorrow over the loss of Yūsūf. In the TT, the translator adopts a different structure to convey the lamentation. An exclamatory sentence is used, thereby resulting in an overtranslation.

\section{b) Tenor}

The verse expresses the lamentation of Jacob by using the vocative. A specific event is behind his lamentation. The children of Jacob told their father that Binyanmīn, who is Yüsūf's brother, has stolen the measuring cup of the king, and thus is in the custody of the king. This event was a good opportunity for Jacob to release his sorrow for Yūsūf, because he realized that the same manner is used to get rid of Yüsüf. In this sentence, Jacob called out to something abstract instead of calling out to the Almighty. This was

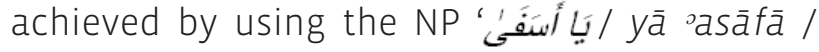
How great is my grief.' The translator placed the participants in the same status and role, and no definite change in meaning was made.

c) Mode

A declarative sentence is embedded in this Qur 'anic vocative sentence. The vocative sentence comprises two main phrases, as follows: the NP 'بَاِلَسَفَى / yā asafā / How great is my grief' and the PP 'عَلَّ ليُوسُفَ / calà Yüsūfa / for

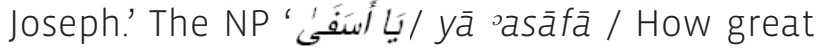
is my grief' becomes the core of the rhetorical meaning of this Qur'anic sentence. The sentence comprises the vocative particle ' $L / y \bar{a} / 0$ ' and the NP 'بَأَسَفَّى / yā rasāfā / my grief.' The call is directed to something abstract, namely, rasāfā. This kind of call is topical because it deviates from the original principle, which involves calling out to a person. The vocative particle is characterized by a prolonged sound to express the extent of Jacob's sorrow over his son. Moreover, the speaker, i.e., Jacob, seems to ask 'أسَفَفَ 'asāfā/grief' to come because the current situation is suitable. The final alif of the lexical item 'asāfā substitutes for the first person possessive 
pronoun 'يفي 'أسفى/my' and the phrase becomes 'asāfā/grief' instead of 'أسفي / aasāfĩ / my grief.' The translator retains the context of this vocative sentence, and the rhetorical purpose is also retained.

\subsection{Exclamation Rhetorical Purpose}

$\operatorname{Data}(3)$

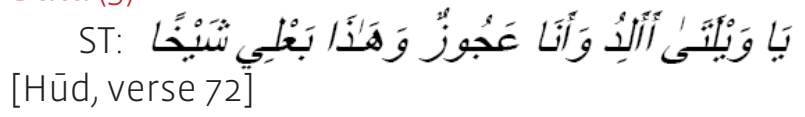

Trs: Yā waylatā 'a ’alidū wā anā cajūzun wā hada bacli šahan

TT: Alas for me! Shall I bear a child, seeing I am an old woman and my husband is an old man (Ali, 2006: 530)

a) Field

The vocative Qur'anic sentence tells about the wonder of Ibrabhim's wife when the messengers of Allah told her that she would have a baby (Al-razī, 2000: 23). The vocative by exclamation is transferred by using specific linguistic lexical

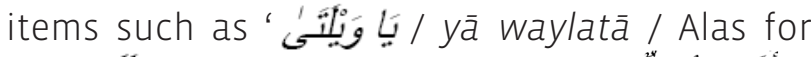

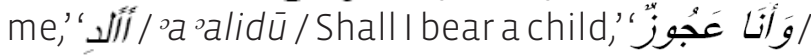
wà anā cajūzun / I am an old woman,' and

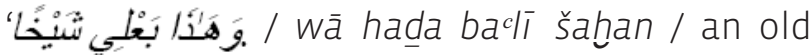
man." The new field in the translation differs from the source field. The field is converted from exclamation to grief. The vocative NP expression is transformed into the exclamatory expression 'Alas for me!' to convey the woman's grief. As such, the translation is inaccurate.

\section{b) Tenor}

The vocative in this Qur'anic vocative sentence is uttered by Ibrabhim's wife when told that she would have a child. The main participants in the tenor of this Qur 'anic vocative sentence are the messengers of Allah, Ibrabhim's wife, and her husband, Ibrabhim. The messengers of Allah (i.e., the angels) brought good news. The angels told the woman that she would have a child, Ishaq, and subsequently, Jacob. This is clear in verse no. 71 of sūrat Hūd ' / fà bašrnahā bi Ishạa wā min wara’ Isḥaq yåqub / But we gave her glad tidings of Isaac, and after him, of Jacob' (Ali, 2006: 229).

Her wonder of this miraculous event is due to several reasons:

1. She is sterile.

2. She is an old woman.

3. Her husband is also an old man.

4. She will live to see her grandson Jacob.

Her wonder is due to a familiar Arab tradition and not due to the ability of the Almighty Allah. A person disbelieves in Allah if he or she expresses wonder at the ability of Allah. The translator has retained the roles and the statuses of all participants in the English translation.

\section{c) Mode}

The exclamation in this Qur 'anic vocative sentence is expressed using particular lexical

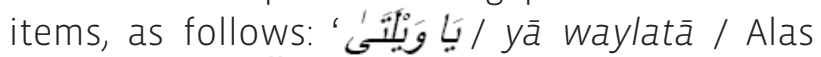

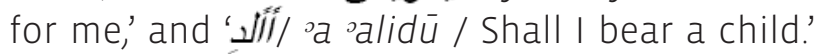

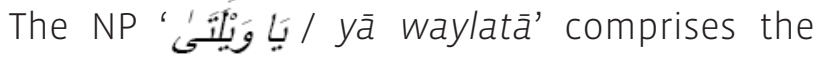
vocative particle ' something far from the speaker, i.e., Ibrabhim's wife. The vocative exclamation is conveyed using a vocative sentence containing an interrogative element. The vocative particle ' characterized by a prolonged sound to show the degree of her wonder

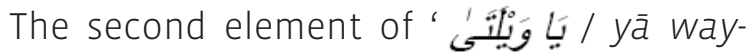
latā / Alas for me' is of major significance. The N

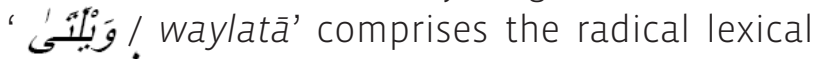
item 'و wayl / Alas' suffixed by the redundant letter " $T$ " to strengthen the meaning. The final alif takes the place of the first person possessive pronoun to produce waylati. Linguistically, the word 'و wayl / Alas' means "disgrace" (Farrāo, 2000: 23). The lexical item 'و ويل / wayl' is also used in Arabic in the context of surprise. The speaker uses this lexical item to strongly express her feelings. The translator has transformed the themat-

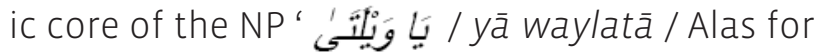
me, thereby changing the meaning of the phrase 
to 'Alas for me!' The thematic core is transformed from exclamation to grief. A close look at this NP reveals that the translator has changed the major rhetorical meaning of this Qur 'anic vocative sentence, and a different meaning is presented. Thus, the translation is inaccurate.

Moreover, the interrogative particle 'i/sa' preceding the VP' 'أ I I ' oa oalidū / shall I bear a child' deviates from its main interrogative function to an exclamatory function. In other words, Ibrabhim's wife conveys her wonder by using an interrogative statement. The interrogative particle ' $/$ / $a$ ' is transposed to the auxiliary verb (V), 'shall,' to indicate that the action will occur in the future. This translation for the interrogative particle ' $1 /{ }^{\circ} a$ ' is accurate because of the following reasons:

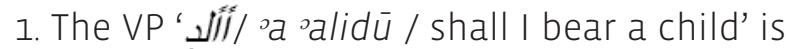
in the present tense with future relevance.

\section{Pregnancy requires a long duration.}

Other means are used to emphasize that the rhetorical meaning of this Qur 'anic vocative sentence is an exclamation. The lexical items,

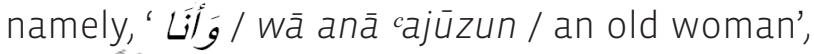

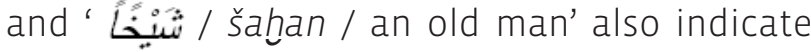
her wonder. Both the man and the woman are old, and giving birth to a child at their age is considered improbable according to the standards for human beings. The following sentence

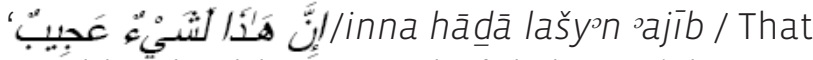
would indeed be a wonderful thing!' (Ali, 2006: 530) also expresses her wonder. In this sentence, Ibrabhim's wife emphasizes her wonder to the messengers of Allah by means of the emphatic

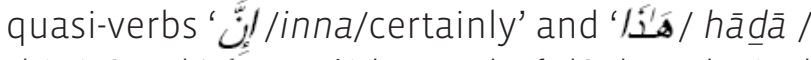
this is,' and 'عَدِّirb/wonderful.' These lexical items refer to and emphasize that her pregnancy at this age is surprising. The translator transformed this sentence into 'That would indeed be a wonderful thing!' (Ali, 2006: 530). The translator attempts to recreate the same expression of wonder in the TT. Unfortunately, the meaning of this sentence is incongruent to that of the pre- vious vocative sentence. In the previous voca-

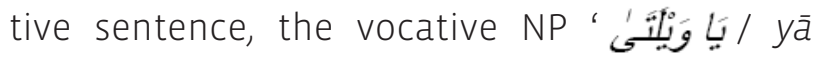
waylatā' is translated as mentioned earlier, i.e., 'Alas for me!' Such unfamiliar realization of the context garbles the rhetorical meaning of this Qur'anic vocative sentence. Consequently, the translation has entirely affected the context of this sentence.

Data (4)

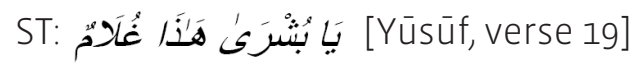

Trs: Yã bušrā hadāà gulāmūn

TT: Ah there! Good news! Here is a (fine) young man! (Ali, 2006: 551)

a) Field

This vocative sentence is characterized by an exclamation. A group of travellers found Yūsūf when they sent a man to obtain water for them. The man was surprised when he saw Yūsūf inside the well. He shouted loudly in his surprise at finding a beautiful boy inside the well. He expresses his feeling of wonder by call-

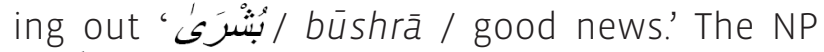

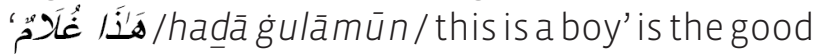

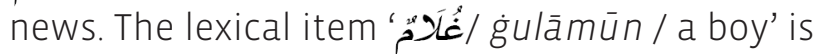
the reason why he called out 'بَا بُشْرَى / yā bušrā / O good news!' The translator has retained the same field in the TT to a particular degree. However, further information that is not available in the ST is provided in the TT, thereby creating a

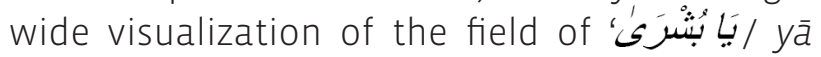

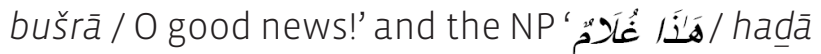
ġulāmūn / this is a boy.' Thus, the translated vocative sentence was overtranslated.

\section{b) Tenor}

In the ST, the participants involved are the group of travellers, the one drawing water, and Yūsūf himself. These participants have varying roles in this sentence. The man drawing water from the well has an important role because he was sent by the group of travellers to get water. Furthermore, the man drawing water from the well is the participant who calls out ' 
yā bušrā / O good news!' when he saw Yūsūf in the depths of the well. The second important participant in this vocative sentence is Yüsūf himself, who is the reason for the statement

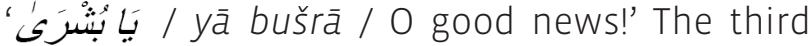
participant is the group of travellers, to whom

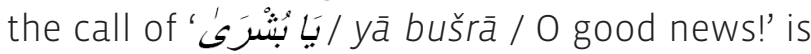
directed. The translator chose to include the boy (i.e., Yūsūf) among the participants. Yūsūf is described in the translation with extra information that is not found in the ST, i.e., a fine young man. Therefore, this sentence was overtranslated.

\section{c) Mode}

The Qur 'anic vocative sentence has a particular rhetorical purpose, which is vocative by exclamation. This purpose is expressed using a vocative sentence with a declarative purpose. This vocative sentence contains two NPs. The first

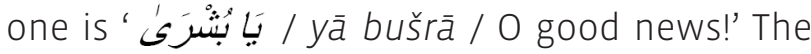
first NP comprises the vocative particle 'يالَّ/yāo,' which is used to call something that is abstract and located far from the speaker. This vocative particle is characterized by a prolonged phonemic sound. The vocative noun is the lexical item 'ابْتُرَنَ / bušrāa / good news.' The speaker, i.e., the man drawing water from the well, calls out to something abstract. In a sense, the speaker uses the lexical item ' بُنْسُرَى / bušrā / good news' to strongly express his feelings. The TT and the ST of ' بَا بُشُْرَى / yā bušrā / O good news!' differed. In the TT, the translator attempts to introduce information that is absent in the ST. The translator attempts to convey his conceptualization in this situation and changes the vocative particle 'يَ/yā/O' into an NP ('Ah there!') in the form of an exclamatory expression. The interjection, 'Ah there!' is an exclamation. The translator did well in choosing this interjection as an equivalent of the vocative particle ' 'يَ/yā/O.' The lexical item 'there' is an adverb (Adv) that is used to call a person (Longman, 2005: 1719). The translator attempts to confirm the situation of finding a beautiful boy. The lexical item 'بُشْرَ / bušrā/ good news' was changed from an $\mathrm{N}$ to a different class. This lexical term is translated into an adjectival phrase (AP; i.e., 'good news'). This shift is necessary to retain the meaning of the ST 'بُشْرَ ' / bušrā / good news.' In general, the sentence was overtranslated.

The second NP comprises the demonstrative pronoun ' 'هَ' / had̄a / this is', that functions

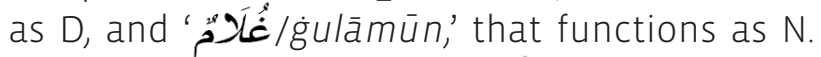
The translator has changed 'Lَ' / hadā / this is' to an Adv (i.e., 'here'). This shift is necessary to retain the secondary meaning of the ST 's's/hada,', which harmonizes with this vocative sentence's context of situation.

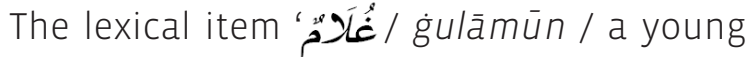
man' is an N transposed to an AP 'a (fine) young man!' The translator has distorted the internal

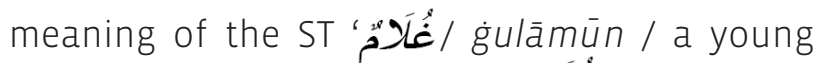

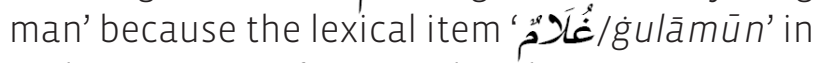
Arabic society refers to a boy between ages 11 and 17 years old. However, the lexical item "a young man" refers to a man older than 17 years

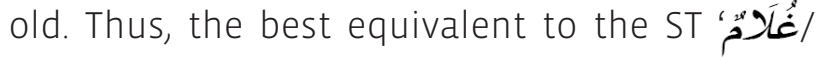
gulāmūn' is the lexical item "a boy." The transIation has partially affected the context of this vocative sentence.

\subsection{Call for help Rhetorical Purpose}

Data (5)

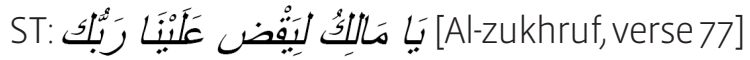

Trs: Yā Māliku li yaqụi calaynā rabbuka

TT: O Mãlik! would that thy Lord make an end to us! (Ali, 2006: 1279)

a) Field

The above Qur anic vocative sentence is a "call for help" at a specific place and time. This shouting is uttered by non-believers who stay in Hell on the Day of Judgment. This appeal for aid is expressed using particular phrases which consist of NP ' 'بَاِ مَالكُّ / yã Māliku / O Mãlik,' V phrase

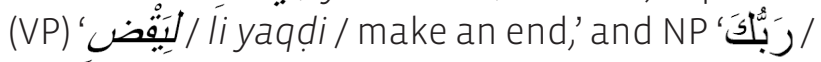
rabbuka.' 
Behind this "call for help," the shouting of unbelievers rises higher to indicate their bad situation in Hell. This "call for help" is conveyed

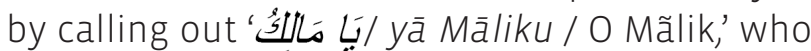
is the one responsible for Hell, and who is considered a fake helper from whom the aid is asked because the real saver is the Almighty Allah.

In the TT, the translator fails to grasp the events in the ST. The translator attempts to recreate the same situation, but he fails to convey the same event in the TT. He tries to change the imperative form ' $J$ /lam' in the ST to wish form 'would that.' The message of the TT is different from that of the ST. The wish form 'would that' is used to express one's desire to fulfil something that might or might not occur (Taiy, 2004: 136). Thus, the translation is inaccurate because the rhetorical meaning is transformed from a call for help to a wish.

\section{b) Tenor}

The participants of the Qur 'anic vocative sentence in both ST and TT are the same. The role of the participants is represented as non-believers, who are recognized by the third person masculine plural pronoun 'و أَنَادَوُا' wa nadū / they will cry.'

The second participant is ' lik, the keeper of Hell, from wnom the help is asked by the non-believers. The main participant is the Almighty Allah, from whom the help is asked. The speakers in this vocative sentence are represented as non-believers, who request ' مَألكُ Māliku/Mãlik' to save them from Hell by exterminating them, i.e., killing them, because of the severe torment in Hell. Such torment is mentioned

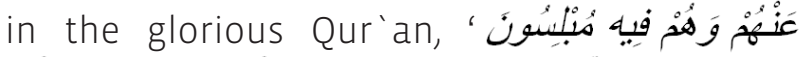

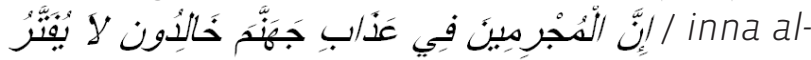
müğrinina fì oadbi ğahānnama halidūn la üftar sanhm wā hum fĩhi müblisüna / The sinners will be in the Punishment of Hell to dwell therein (for aye): Nowise will the (Punishment) be lightened for them, and in despair will they be there overwhelmed' [Al-zūhruf, verse 74-75] (Ali, 2006: 495).
The roles and the statuses of the participants in the sentence have been retained in the TT.

c) Mode

The Qur 'anic vocative sentence implies an imperative sentence, which was uttered by the non-believers to ask help from ' مَالِكَ /Māliku/Mãlik', and to ask Allah to end their suffering. In this sentence, the vocative expression is realized by the NP ' 'بَاِ مَالكِكُ / yā Mâliku,' which includes the vocative particle ' بَاِ

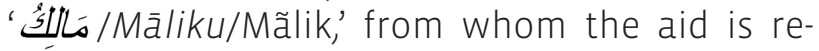
quired. The vocative noun is expressed in Arabic as almustagit ti or almustgatbihi. The vocative noun 'مَالكَّ/Māliku/Mãlik' is considered minor almustgatbihi because the major almustgatbih from whom the aid is required is the Almighty Allah. This focus has been retained in the TT, which includes two participants from whom the aid is required. Furthermore, the vocative sentence diverges from the structure and the rules established by Arab grammarians. This deviation from the original criteria is considered a satisfactory proof of the rhetorical and aesthetic aspect of the glorious Qur'an.

The VP 'الَهْضِ / li yaqdi / make an end' comprises two lexical items, as follows: the imperative 'J/lam' and the imperfect V 'بَفْض / yaqdi / make an end,' which is conveyed through jussive mood. The translator has presented a clear shift involving the ST imperative 'J/lam.' Such imperative is transformed to the wish form 'would that' to express the desire of the non-believers to be put to death by the Almighty Allah. A wish is used to express a desire that might or might not be granted. This wish goes against the real situation of the non-believers in Hell, because they are not in a position to wish for anything. These non-believers are suffering severely from continuous physical torment in Hell. As a result, the translator has given a new meaning from that in the ST. The rhetorical meaning has been distorted because the translator failed to infer the correct meaning of the ST. Thus, the context of this 
vocative sentence has been affected entirely by translation from Arabic into English.

\section{Data (6)}

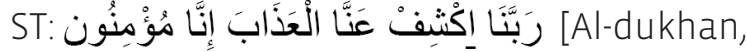 verse 12]}

Trs: rabbanā sikšif cannā al-cadaba sinnā mưminūna

TT: Our Lord! Remove the Penalty from us, for we do really believe! (Ali, 2006: 496)

a) Field

The Qur'anic vocative sentence considers the manner of torture endured by the Quraysh pagans who do not believe in Almighty Allah and his messenger Prophet Muhammad (PUH). The sentence also conveys the feelings of believers who want relief from their torture as non-believers of Quraysh. The believers ask the Almighty Allah to relieve their torture because they believe Him and His messenger. The call for help is conveyed through the omitted device of the voca-

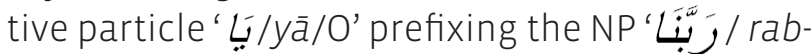
bana / our Lord.' The lexical item 'اكتشفن / Jikšif/ remove' is an imperative $V$ that implies the call for help. The lexical item 'الْعَذابَ / al-cadaba / the penalty' is the actual attached event. The lexical item ' مُوْْهنُونُ / mu’minūna / do really believe!' is considered the reason for which these believers are calling for help. The rhetorical purpose of this vocative sentence might result in an important event. The purpose of this vocative implies the "call for help" because of the following:

1. The vocative conveys a particular situation of torture, which befell the people of Quraysh in the form of drought.

2. The demand is uttered by believers who are imploring for salvation because they believe in Allah and his messenger. This demand is asserted by the lexical word 'مُوِْْنُونَ mưminūna / do really believe!'

3. No convincing proof exists that the people of Quraysh promised the prophet Muhammad (PUH) their belief in exchange for relief from drought (Ibn ªšūr, 2000: 318).

4. The call for help is used in a critical and difficult situation, whereas the invocation is used in both difficult and non-difficult situations. Consequently, each vocative sentence with the "call for help" purpose implies an invocation, not the reverse.

5. The lexical item 'إنَّا / inna / we are' indicates that the believers did not promise to be believers because they already believe in Allah. Moreover, these believers did not say that they would believe in Allah if He lifts the torture (Ibn 'ašūr, 2000: 318). In the scope of the translation, the field's general status has been retained by the translator.

\section{b) Tenor}

The roles and the statuses of the participants are clear in this Qur anic vocative sentence. The participants involved in this sentence are as follows: the believers are the main participants who are asking for help and the Almighty Allah, from whom the help is required. The torture is the result of the request of the prophet Muhammad to Allah. The prophet asked Allah to torture the people of Quraysh, because they refuse to believe in Allah and in himself. This torture is represented by a drought, as stated in the

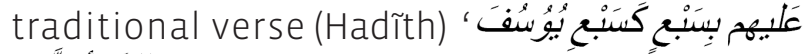
اللَّهم أَعَّنَي Yüsüfa / O my Lord help me against them by a severe dearth similar to years of Yūsūf 's dearth.' The translation was slightly inaccurate because of the confusion in the role of the participants, i.e., the role of the believers. Whether or not the speakers of this sentence are the real believers is not indicated nor clarified.

\section{c) Mode}

The vocative sentence is accompanied by an imperative sentence. The vocative sentence comprises a range of phrases that have an important function in presenting the rhetorical meaning of "call for help." The NP ' 'رَبَّنَ / rabbanā / our Lord' is the vocative noun phrase with an im 
plicit vocative particle ' 'بَ/yā/O.' Two important aspects are observed when the vocative particle ' 1 - mode) that dropping the vocative particle according to the believers is an indicator of Allah's closeness to the people during their ordeal. Such closeness enables them to quickly ask for Allah's help. This omission is also seen in the translation of the NP ' 'رَزَّبَّ/ rabbanā / into (our Lord!),' which is followed by the exclamation mark. This translation conveys the same state and effect of the vocative by an exclamatory expression. The

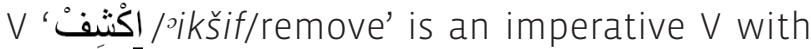
an implicit subject (You). The primary meaning

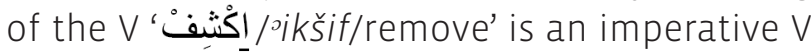
that implies action performed by the addressee. The imperative $V$ occasionally deviates from its primary meaning to other new meanings, such as a request, command, and warning. In this case, the secondary and new meaning of the $V$ 'اكُشَفَْْ/oikšif/remove' is "call for help." Such new meaning is also rendered into the imperative $V$ 'remove.'

The lexical item 'الْعَذَابَ / al-cadaba / the penalty' is an NP that means "torment." This lexical item means cruel physical and mental suffering. The term conveys a horrible vision of a difficult situation. The translation was an unsuitable equivalent that fails to comply with the context of physical suffering of the Quraysh people, in general, and the believers in particular. The term is translated into "the penalty," which conveys punishment for breaking a law, a rule, or a legal agreement. Thus, the translator failed to envision the real situation in which this lexical word was used in this vocative sentence. Consequently, the rhetorical meaning of "call for help" in the vocative sentence was slightly distorted when translated to English.

\section{Conclusion}

In this study, the context of the Qur'anic vocative sentences and their translation were analysed by using Halliday and Hassan's (1985) register's theory, and according to the register variables, namely, field, tenor, and mode. In the process of translation to English, changes are made in the context of the Qur anic vocative sentences. The translation has entirely affected the context of particular vocative sentences. The meaning of some sentences has been partially affected, whereas those of others have been retained in the English translation. Thus, the rhetorical message was lost or transformed in the process of translation. Other rhetorical messages in the target language have been preserved. Register theory enables the identification of the rhetorical message of the Qur'anic vocative sentences in both ST and TT. The variables of Halliday `s theory have provided complementary devices in our analysis of the nature and extent of the retention of rhetorical messages in the English-translated Qur`anic vocative sentences. Moreover, various observations, such as inaccurate translation, overtranslation, and communicative translation, were made.

\section{Bibliographic references}

Aвu Musa, Moḥammad, 1987: h̦șåiṣ AL-Tarakíb: Dirasa Taḥlilya Li-Masāoil cilm-Macāni, Maktabat Wahbah.

'ALAwī, Yaḥya, 1982: AL-Tirāz Al-Mutaḍamin Li-Asrar Al-Lugahh wā cilm haqaaiq Al-lcğāz, Dār AlKutub AL-ciilmiyah.

Așfahanī, Ragiib, 1992: Mufradat Alfaż Al-Qur' an AlKarĩm, Dār Al-Kutub Al-cilmiyah.

FARRĀ, Moḥammad, 2000: Ma’ānī Al-Qur'ān, cālam Al-Kutub.

Fūd, Basūnī, 1998: cilm Al- Mãānī-Dirasha Balagiiyah wā Naqdiyah li-Masāoil Al-Mãāní, Cairo, Mưasasat Al-Muhtar lilnašr wā Altawzīo

Halliday, M. A. K. \& Ruqayia Hasan, 1985: Language, Context and Text: Aspects of Language in a Social-Semiotic Perspective, Deakin University Press. 
Halliday, M. A. K., 1978: Language as Social Semiotic: The Social Interpretation of Language and Meaning, U. K. Edward Arnold Ltd.

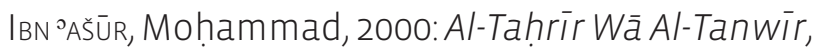
Murasasat Al-Tarih.

Morley, G. D., 1985: An Introduction to Systemic Grammar, Macmillan Publishers Ltd.

QAzwinī, Moḥammad, 1983: AL-Iḍāḥ fì cilm AlBalaġah, Dār Al-Kitāb Al-Lubnanī.

Razī, Mohammad, 2000: Al-tafsìr Al-kabìr, Dār Alkutub Al-cilmiyah.

ȚAly, Hassan, 2004: Surrat Al-Maida wa Maryam: Muwazana Balagiiyya dimna cilm Al- Macāni (unpublished Master Thesis), University of Mosul.

Yusuf, Abdullah, 2006: The Meaning of the Holy Qur'an, Amana publications.

ZaWBAcīi Țālib, 1997: AL-Balag̉ah Al-carabiyah - cilm Al-Macāní, Bayan Balag̉at Al-Qudamā wā Uslubiyat Al-Muhditîn, Qaryounis, University Benghazi. 